\title{
35. ORGANIC FACIES AND MATURATION OF SEDIMENTS FROM THE TYRRHENIAN SEA, OCEAN DRILLING PROGRAM, LEG 107¹
}

\author{
Prasanta K. Mukhopadhyay²
}

\begin{abstract}
Thirty sediment samples from Tortonian to Pleistocene age of five ODP locations (Holes 650A, 651A, and 652A, and Sites 654 and 655) in the Marsili Basin, Vavilov Basin, and Sardinia Margin (Tyrrhenian Sea) were studied by organic geochemical methods including total organic carbon determination, Rock-Eval pyrolysis, bitumen extraction, pyrolysis-gas chromatography, and organic petrography. Six organic facies, including open ocean anoxia with variable terrestrial input, oxic open ocean, oxic tidal flat, mildly oxic lagoon, and anoxic lacustrine algal-bacterial mat environments, have been recognized in these sediments. The sediments below $500 \mathrm{~m}$ in Sardinia Margin are mature for significant hydrocarbon generation. Possible mature source-rock (Type I and IIB/III kerogen) and migrated bitumen occur in the deeper part of the section in Vavilov Basin and Sardinia Margin sediments. Sporadic sapropel formation observed in the studied Pliocene-Pleistocene sediment section is probably controlled by organic productivity due to nutrient supply by the rivers and terrestrial input associated with open ocean anoxia or anoxia caused by the material balance between rate of organic matter supplied by turbidites and organic matter consumption. Pliocene and Pleistocene sapropels are mostly immature and lie within Type II-III (precisely as IIA-IIB and IIB source rocks) kerogen maturation path.
\end{abstract}

\section{INTRODUCTION}

Leg 107 drilled a transect of seven sites from young passive continental margin to an even younger oceanic type basin in the Tyrrhenian Sea (Leg 107 Scientific Party, 1986a, b) as shown in Figure 1A. The Tyrrhenian Sea is a small triangular sea surrounded by the mainland of Italy, Sicily, Sardinia, and Corsica (Fig. 1B). Leg 107 investigated how a back-arc basin which opened behind a volcanic arc and above a subduction zone evolves in time and space. Sites 652, 653, and 654 (Sardinia Margin) documented syn-rift and post-rift sedimentary units. Evaporites, laminated mudstone, and other clastics of Messinian or Tortonian age are overlain by open-marine Pliocene and Pleistocene nannofossil ooze in all the sites. Organic-rich black, gray, and green mudstone or claystone (sapropel ${ }^{3}$ and sapropelic layers, Kidd et al., 1978) are mainly associated with Pliocene and Pleistocene nannofossil ooze. Two deep basins (Site 650Marsili Basin and Site 651-Vavilov Basin) contain Pliocene and Pleistocene sedimentary sequence with abundant nannofossil ooze. Both of these sites contain several organic-rich black and gray mudstones mainly near the boundary of Pliocene and Pleistocene age.

The objectives of this research are to investigate the amount, type, and maturation of the soluble and insoluble organic matter in various sediments. These data from the soluble and insoluble organic matter provide information about the organic facies of different sapropel, sapropelic layers, and other sediments. Interpretation of organic facies will eventually reveal the depositional environments and source-rock potential of both organic-rich and organic-lean sediments.

\footnotetext{
${ }^{1}$ Kastens, K. A., Mascle, J., et al., 1990. Proc. ODP, Sci. Results, 107: College Station, TX (Ocean Drilling Program).

2 Global GeoEnergy Research, R.P.O. Box 23070, Dartmouth S.C., Nova Scotia, Canada B3A 4S9.

${ }^{3}$ According to Kidd et al. (1978), sapropel is a discrete layer, greater than $1 \mathrm{~cm}$ in thickness and deposited in open marine pelagic sediments having more than 2 wt $\%$ organic carbon content. A sapropelic layer is similarly defined but it contains between $0.5 \%$ and $2 \%$ organic carbon.
}

\section{METHODS}

\section{Samples}

Thirty samples from five holes (four from $650 \mathrm{~A}$, six from 651A, thirteen from $652 \mathrm{~A}$, four from 654 , and three from 655 ) were analyzed with a Leco carbon analyzer and with Rock-Eval pyrolysis. Twelve samples were chosen for vitrinite reflectance and maceral composition, ten for bitumen extraction, and five for pyrolysis-gas chromatography. Table 1 provides information on depth, stratigraphy, and lithology of these samples. The originally frozen samples were dried at $50^{\circ} \mathrm{C}$ for $12 \mathrm{hr}$ and crushed for kerogen and bitumen analysis.

\section{Experimental Procedures}

Total organic carbon was determined with a LECO (EC 12) carbon analyzer after treatment of the sediments with $4 \mathrm{~N} \mathrm{HCl}$ to remove carbonate carbon. Rock-Eval pyrolysis (Rock-Eval II) was performed according to the method described by Espitalie et al. (1977). Hydrogen and oxygen contents of the rock samples, measured as pyrolytic hydrocarbon compounds and carbon dioxide yields, respectively, were normalized to total organic carbon content and displayed as index values in a modified (oxygen index up to 400 instead of $150 \mathrm{mg} \mathrm{CO} / \mathrm{g} \mathrm{TOC}$ ) van Krevelen type diagram adopted from Espitalie et al., (1977). Four partially demineralized samples were also analyzed in order to document the mineral matrix effect on Rock-Eval pyrolysis. The kerogen isolation procedure included treatment with $20 \% \mathrm{HCl}$ and $70 \% \mathrm{HF}$.

Maceral composition analysis was done by point counting using white transmitted and reflected light (white and blue-light excitation) microscopy with smear slides and polished plugs prepared from kerogen concentrates. For detailed description (except sapropelinite IIA and IIB) of different maceral types of vitrinite, inertinite, and liptinite groups such as telocollinite, desmocollinite, fusinite, sclerotinite, liptodetrinite, alginite, particulate liptinite $\mathrm{A}$, sporinite, sapropelinite I, humosapropelinite, etc., refer to Stach et al. (1982) and Mukhopadhyay et al. (1985a). For the definition of sapropelinite IIA (amorphous liptinite) and sapropelinite IIB, see Appendix. Vitrinite reflectance was measured on a Zeiss UMSP 30 microscope with MPM 03 photomultiplier system according to the standard procedures of Stach et al. (1982). The boundary of autochthonous and allochthonous vitrinite was determined according to oxidation features, bimacerite grains, and autochthonous inertinite reflectance (Mukhopadhyay et al., 1985b).

Pyrolysis-gas chromatography was done using a Chemical Data System (CDS) model 820 GS Reaction System. In the pyrolysis-gas chromatography, samples were placed in a desorption probe in the cooled interface and heated at the rate of $30^{\circ} \mathrm{C} / \mathrm{min}$ from $250^{\circ}$ to $600^{\circ} \mathrm{C}$. Organic 

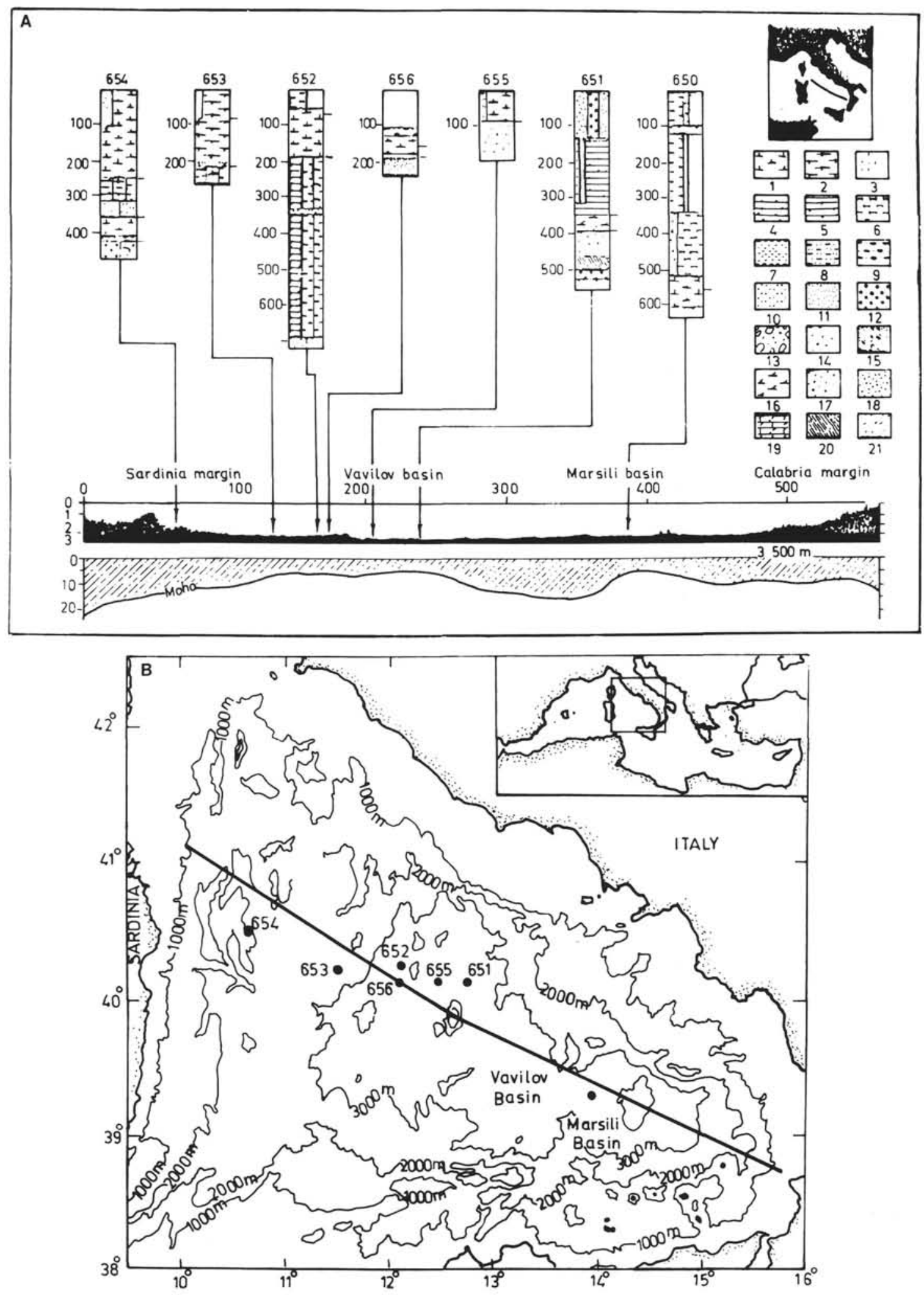

Figure 1. A. Lithology and cross-section of seven boreholes drilled in Tyrrhenian Sea; inset showing location of the crosssection. B. Location of seven boreholes drilled in Tyrrhenian Sea and line of cross-section. 
Table 1. Sample, lithology, stratigraphy, organic carbon, and Rock-Eval pyrolysis data.

\begin{tabular}{|c|c|c|c|c|c|c|c|c|c|c|}
\hline \multirow{2}{*}{$\begin{array}{l}\text { Hole-core-section } \\
\text { interval }(\mathrm{cm})\end{array}$} & \multirow{2}{*}{$\begin{array}{l}\text { Sub-bottom } \\
\text { depth } \\
\text { (m) }\end{array}$} & \multirow{2}{*}{$\begin{array}{l}\text { Lithology } \\
\text { and } \\
\text { stratigraphy }\end{array}$} & \multirow{2}{*}{$\begin{array}{l}\text { TOC } \\
(\%)\end{array}$} & $\mathrm{S}_{1}$ & $\mathrm{~S}_{2}$ & $\mathrm{~S}_{3}$ & \multirow{2}{*}{$\begin{array}{c}\text { Hydrogen } \\
\text { index }^{\mathrm{a}}\end{array}$} & \multirow{2}{*}{$\begin{array}{l}\text { Oxygen } \\
\text { index }\end{array}$} & \multirow{2}{*}{$\begin{array}{c}\text { Production } \\
\text { index } \\
\mathrm{S}_{1} / \mathrm{S}_{1}+\mathrm{S}_{2}\end{array}$} & \multirow{2}{*}{$\begin{array}{l}\mathrm{T}_{\max } \\
\left({ }^{\circ} \mathrm{C}\right)\end{array}$} \\
\hline & & & & \multicolumn{3}{|c|}{$\mathrm{mg} / \mathrm{g}$ of rock } & & & & \\
\hline $650 \mathrm{~A}-50-4,106-108$ & 455.96 & $\begin{array}{l}\text { Dk gr calc mud } \\
\text { Pleistocene }\end{array}$ & 2.17 & 0.27 & 4.73 & 2.35 & 217 & 108 & 0.05 & 419 \\
\hline $650 \mathrm{~A}-50-4,138-141$ & 456.28 & Same as above & 2.49 & 0.32 & 6.27 & 2.53 & 251 & 102 & 0.05 & 417 \\
\hline $650 \mathrm{~A}-51-3,92-94$ & 464.02 & $\begin{array}{l}\text { Lt gr mud } \\
\text { Pleistocene }\end{array}$ & 1.08 & 0.08 & 0.83 & 1.66 & 77 & 154 & 0.09 & 414 \\
\hline $650 \mathrm{~A}-64-2,51-53$ & 586.41 & $\begin{array}{l}\text { Lt gr mud } \\
\text { Up. Pliocene }\end{array}$ & 0.72 & 0.04 & 0.67 & 1.87 & 93 & 260 & 0.06 & 419 \\
\hline $651 \mathrm{~A}-27-2,68-69$ & 253.78 & $\begin{array}{l}\text { Dk gr nan mud } \\
\text { Pleistocene }\end{array}$ & 1.76 & 0.49 & 3.25 & 2.60 & 184 & 148 & 0.13 & 411 \\
\hline $651 \mathrm{~A}-28-\mathrm{C}, 1-2$ & 271.71 & $\begin{array}{l}\text { Dk gr mud } \\
\text { Pleistocene }\end{array}$ & 1.85 & 1.08 & 4.32 & 4.09 & 234 & 221 & 0.20 & 415 \\
\hline $651 \mathrm{~A}-35-1,6-8$ & 323.66 & $\begin{array}{l}\text { Lm bl mud } \\
\text { Pleistocene }\end{array}$ & 2.31 & 0.34 & 6.84 & 3.00 & 296 & 130 & 0.05 & 426 \\
\hline $651 \mathrm{~A}-36-1,54-56$ & 334.14 & $\begin{array}{l}\text { Lm bl mud } \\
\text { Pleistocene }\end{array}$ & 3.65 & 0.43 & 10.71 & 3.17 & 293 & 87 & 0.04 & 420 \\
\hline $651 \mathrm{~A}-36-3,7-10$ & 336.67 & $\begin{array}{l}\text { Dk gr calc cls } \\
\text { Pleistocene }\end{array}$ & 1.32 & 0.61 & 1.82 & 3.97 & 138 & 301 & 0.25 & 425 \\
\hline $651 \mathrm{~A}-37-2,107-110$ & 370.37 & $\begin{array}{l}\text { Dk gr mud } \\
\text { Up. Pliocene }\end{array}$ & $\begin{array}{r}2.18 \\
\mathrm{c}_{19.77}\end{array}$ & $\begin{array}{l}0.78 \\
5.64\end{array}$ & $\begin{array}{r}7.74 \\
101.80\end{array}$ & $\begin{array}{r}4.30 \\
13.02\end{array}$ & $\begin{array}{l}355 \\
515\end{array}$ & $\begin{array}{r}197 \\
66\end{array}$ & $\begin{array}{l}0.09 \\
0.05\end{array}$ & $\begin{array}{l}423 \\
411 \\
\end{array}$ \\
\hline $652 \mathrm{~A}-3-2,1-2$ & 28.21 & $\begin{array}{l}\text { Dk gr mud } \\
\text { Pleistocene }\end{array}$ & 2.14 & 0.60 & 4.31 & 3.06 & 201 & 143 & 0.12 & 414 \\
\hline $652 \mathrm{~A}-6-1,40-42$ & 55.80 & $\begin{array}{l}\text { Lm bl mud } \\
\text { Pleistocene }\end{array}$ & $\begin{array}{r}5.49 \\
c_{20.49}\end{array}$ & $\begin{array}{r}1.87 \\
11.58\end{array}$ & $\begin{array}{l}16.22 \\
85.05\end{array}$ & $\begin{array}{r}4.75 \\
18.74\end{array}$ & $\begin{array}{l}295 \\
415\end{array}$ & $\begin{array}{l}87 \\
91\end{array}$ & $\begin{array}{l}0.10 \\
0.12\end{array}$ & $\begin{array}{l}411 \\
399\end{array}$ \\
\hline $652 \mathrm{~A}-6-1,45-47$ & 55.85 & Same as above & 4.32 & 1.75 & 10.37 & 6.02 & 240 & 139 & 0.14 & 415 \\
\hline $652 A-7-4,32-34$ & 69.70 & $\begin{array}{l}\text { Lt gr nan ooz } \\
\text { Pleistocene }\end{array}$ & 0.56 & 0.23 & 0.77 & 3.29 & 138 & 588 & 0.23 & 421 \\
\hline $652 \mathrm{~A}-9-2,37-39$ & 86.07 & $\begin{array}{l}\text { Dk gr mud } \\
\text { Up. Pliocene }\end{array}$ & $\begin{array}{r}2.74 \\
c_{23} .73\end{array}$ & $\begin{array}{r}1.43 \\
12.37\end{array}$ & $\begin{array}{r}9.69 \\
11.16\end{array}$ & $\begin{array}{r}5.17 \\
18.53\end{array}$ & 354 & $\begin{array}{r}189 \\
78\end{array}$ & 0.13 & $\begin{array}{l}420 \\
412\end{array}$ \\
\hline $652 \mathrm{~A}-9-2,96-99$ & 86.69 & Same as above & 2.96 & 0.64 & $\begin{array}{r}111.16 \\
8.09\end{array}$ & $\begin{array}{r}3.58 \\
3.58\end{array}$ & 273 & 121 & 0.10 & $\begin{array}{l}412 \\
420\end{array}$ \\
\hline $652 \mathrm{~A}-20-6,81-82$ & 198.11 & $\begin{array}{l}\text { Lt gr nan cl } \\
\text { Lr Pliocene }\end{array}$ & 0.47 & 0.65 & 0.41 & 3.54 & 87 & 753 & 0.61 & 429 \\
\hline $652 A-31-1,4-6$ & 295.94 & $\begin{array}{l}\text { Lt gr gp mud } \\
\text { Messenian }\end{array}$ & 0.18 & 0.11 & 0.02 & 1.76 & 11 & 978 & 0.85 & 325 \\
\hline $652 \mathrm{~A}-49-1,116-118$ & 472.02 & $\begin{array}{l}\text { Gr br gp mud } \\
\text { Messenian }\end{array}$ & 0.14 & 0.08 & 0.02 & 0.84 & 14 & 600 & 0.80 & 308 \\
\hline $652 \mathrm{~A}-52-4,133-138$ & 504.63 & $\begin{array}{l}\text { Lr gr sd mud } \\
\text { Messenian }\end{array}$ & 0.29 & 0.00 & 0.05 & 0.75 & 17 & 259 & 0.00 & 434 \\
\hline $652 \mathrm{~A}-62-4,142-149$ & 600.82 & $\begin{array}{l}\text { Lt gr dol mud } \\
\text { Messenian }\end{array}$ & 0.42 & 0.03 & 0.16 & 0.97 & 38 & 231 & 0.16 & 434 \\
\hline $652 \mathrm{~A}-64-1,100-102$ & 615.20 & $\begin{array}{l}\text { Lm gr al mud } \\
\text { Messenian }\end{array}$ & 8.86 & 5.30 & 82.72 & 1.08 & 934 & 12 & 0.06 & 435 \\
\hline $652 \mathrm{~A}-73-3,83-85$ & 705.73 & $\begin{array}{l}\text { Lt gr sd mud } \\
\text { Age doubtful }\end{array}$ & 0.35 & 0.18 & 0.14 & 0.98 & 40 & 280 & 0.56 & 421 \\
\hline $654-6-4,146-148$ & 46.26 & $\begin{array}{l}\text { Dk gr calc mud } \\
\text { Pleistocene }\end{array}$ & 3.17 & 1.35 & 7.16 & 7.05 & 226 & 222 & 0.16 & 413 \\
\hline $654-12-1,102-107$ & 99.62 & $\begin{array}{l}\text { Lt gr nan ooz } \\
\text { Up. Pliocene }\end{array}$ & 0.10 & 0.11 & 0.06 & 2.30 & 60 & 2300 & 0.65 & 426 \\
\hline $654-41-1,32-34$ & 358.12 & Pet dk nan ooz & 1.20 & 0.41 & 1.66 & 2.54 & 138 & 212 & 0.20 & 413 \\
\hline $654-42-4,74-76$ & 372.64 & $\begin{array}{l}\text { Tortonian } \\
\text { Lt gr nan ooz } \\
\text { Tortonian }\end{array}$ & $\begin{array}{l}{ }^{c} 6.15 \\
0.33\end{array}$ & $\begin{array}{l}3.49 \\
0.20\end{array}$ & $\begin{array}{r}19.16 \\
0.09\end{array}$ & $\begin{array}{l}4.05 \\
2.10\end{array}$ & $\begin{array}{r}312 \\
27\end{array}$ & $\begin{array}{r}74 \\
636\end{array}$ & $\begin{array}{l}0.15 \\
0.69\end{array}$ & $\begin{array}{l}404 \\
405\end{array}$ \\
\hline $655-2-4,67-68$ & 14.87 & $\begin{array}{l}\text { Lm bl calc cl } \\
\text { Pleistocene }\end{array}$ & 4.11 & 1.67 & 12.11 & 8.00 & 295 & 195 & 0.12 & 416 \\
\hline $655-3-1,67-68$ & 22.98 & Same as above & 4.13 & 1.61 & 11.23 & 8.09 & 272 & 196 & 0.13 & 418 \\
\hline $655-3-5,11-13$ & 28.41 & $\begin{array}{l}\text { Dk gr cl } \\
\text { Pleistocene }\end{array}$ & 2.29 & 0.83 & 3.72 & 5.54 & 162 & 242 & 0.18 & 418 \\
\hline
\end{tabular}

a $\mathrm{mg} \mathrm{HC} / \mathrm{g} \mathrm{TOC}$

$\mathrm{b} \mathrm{mg} \mathrm{CO} / \mathrm{g}$ TOC

${ }^{c}$ Partially demineralized kerogens

Note: $\mathrm{Dk}$ gr calc mud = dark gray calcareous mudstone; $\mathrm{Lt}$ gr mud = light gray mudstone; Dk gr nan mud = dark gray nannofossil mudstone; $\mathrm{Dk}$ gr mud = dark gray mudstone; $\mathrm{Lm}$ bl mud = laminated black mudstone; $\mathrm{Dk}$ gr calc cls = dark gray calcareous claystone; Lt $\mathrm{gr}$ nan $\mathrm{ooz}=$ light gray nannofossil ooze; Lt gr nan cl = light gray nannofossil claystone; Lt gr gp mud = light gray gypsiferous calcareous mudstone; Gr br gy mud = grayish brown gypsiferous mudstone; Lt gr sd mud = light gray sandy mudstone; Lt gr dol mud = light gray dolomitic mudstone; Lm gr al mud = laminated gray algal-rich mudstone; Pet $\mathrm{dk}$ nan $00 \mathrm{z}=$ petroliferous dark nannofossil ooze; $\mathrm{Lm} \mathrm{bl}$ calc $\mathrm{cl}=$ laminated black calcareous claystone; $\mathrm{Dk} \mathrm{gt} \mathrm{cl}=$ Dark gray claystone.

compounds desorbed during the heating $\left(\mathrm{P}_{2}\right.$ fraction) were trapped and detected by a flame ionization detector (FID) after separation by gas chromatograph equipped with a capillary column (007 methyl phenyl $5 \%$ silicone; length $=25 \mathrm{~m}$ and i.d. $=0.25 \mathrm{~mm}$ ). The temperature was programmed from $20^{\circ} \mathrm{C}(6 \mathrm{~min})$ to $300^{\circ} \mathrm{C}$ at a heating rate of $4^{\circ} \mathrm{C} / \mathrm{min}$. Detailed description of pyrolysis-gas chromatography using CDS system was previously described (Whelan et al., 1983).

\section{RESULTS AND DISCUSSION}

\section{Organic Carbon}

Table 1 shows organic carbon content of all analyzed samples from the Holes $650 \mathrm{~A}, 651 \mathrm{~A}$, and $652 \mathrm{~A}$, and Sites 654 and 655 . In the Hole $650 \mathrm{~A}$, organic-carbon-rich sediments occur 
between 450 and 590 mbsf near the Pliocene and Pleistocene boundary; two samples have a TOC value exceeding $2 \%$ and two other samples have values between $0.5 \%$ and $2.0 \%$ TOC having several centimeter thickness which indicate the presence of sapropel and sapropelic layers respectively, according to the definition of Kidd et al. (1978). Similarly in the Hole 651A, three sapropels (more than $2 \mathrm{wt} \%$ TOC) and three sapropelic layers (between 0.5 and $2 \mathrm{wt} \%$ TOC) are present. Four sapropels of several centimeters in thickness occur in the upper $100 \mathrm{~m}$ at Hole $652 \mathrm{~A}$. Between 100 and $600 \mathrm{~m}$ in the Hole $652 \mathrm{~A}$, all the Messinian sediments are organic lean (less than $0.5 \mathrm{wt} \%$ TOC). Except for a thick band of highly organic-rich ( $>8 \mathrm{wt} \%$ TOC) gray laminated mudstone in Core $652 \mathrm{~A}-64-1,100-102 \mathrm{~cm}$, most other sediments in the deeper part of the section are organiclean as seen from the preliminary summary of the drilling results of Leg 107 and from one analyzed sample. In Sites 654 and 655 , four sapropels ( $>2 \mathrm{wt} \%$ TOC) are restricted in the Pleistocene dark gray claystone or calcareous mud $(<75 \mathrm{~m}$ subbottom depth). Some Tortonian nannofossil ooze at Site 654 is organicrich (654-41-1, 032-034 cm: 1.20 wt \% TOC). However, most sediments deeper than $100 \mathrm{~m}$ (subbottom depth) are organiclean $(<0.5 \mathrm{wt} \%$ TOC) as revealed from the results from preliminary drilling data.

\section{Rock-Eval Pyrolysis}

Table 1 shows the Rock-Eval pyrolysis data of thirty analyzed samples. The $\mathrm{S}_{2}$ fractions (pyrolytic hydrocarbon in $\mathrm{mg}$ $\mathrm{HC} / \mathrm{g}$ of rock) of different Pleistocene to upper Pliocene sapropels in various sites vary between 4.31 and 16.22 which is considered to have fair to very good source rock generative potential (Peters, 1986). In general, sapropels from the Hole 652A and Site 655 contain higher $\mathrm{S}_{2}$ fraction $(4.31$ and $16.22 \mathrm{mg} \mathrm{HC} /$ $\mathrm{g}$ of rock) than the sapropels from the Holes $650 \mathrm{~A}$ and $651 \mathrm{~A}\left(\mathrm{~S}_{2}\right.$ between 4.73 and 10.71), and Site 654 . Messinian organic-carbon-rich sediment in Hole 652A (Core 64-1, 100-102 cm) contain anomalously high $\mathrm{S}_{2}$ fraction $(82.72 \mathrm{mg} \mathrm{HC} / \mathrm{g}$ rock) and has very good source-rock potential.

Samples plotted on a hydrogen index (mg HC/g TOC) vs. oxygen index ( $\mathrm{mg} \mathrm{CO}_{2} / \mathrm{g}$ TOC) show that half of the samples are comparable to the shallow marine, nearshore, deltaic, and lacustrine clastic sediments when oxygen index is considered (Fig. 2); half of the sediments have oxygen indices greater than 200 ( $\mathrm{mg} \mathrm{CO}_{2} / \mathrm{g}$ TOC) which is consistent with the earlier studies on deep-sea sediments (Peters and Simoneit, 1982; Rullkotter et al., 1984; Mukhopadhyay et al., 1985a). Messinian organic-carbon-rich sediment $(652 \mathrm{~A}-64-1,100-102 \mathrm{~cm})$ lie on the Type I kerogen evolution path and has highest hydrocarbon potential. All Pliocene-Pleistocene sapropels lie along Type II-III kerogen path; except for Sample 655-3-5, 011-013 cm (TOC $=2.29 \%$ ) which lies within Type III kerogen maturation path. These data may suggest that with one exception, all Pliocene and Pleistocene deep marine black shales (sapropel) lie within kerogen Type II and III (Type IIA-IIB or IIB of Mukhopadhyay, 1989, and Mukhopadhyay et al., 1985a) indicating either a mixed organic (marine and terrestrial) population or partial oxidation of phytoplankton (marine) derived organic matter during deposition. All samples having organic carbon content between 0.5 and 1.5 wt $\%$ TOC, are within Type III kerogen path. Samples containing less than $0.5 \mathrm{wt} \%$ TOC, cluster along the Type IV kerogen evolution path suggesting deposition in a more oxic environment (example: open marine).

Four partially demineralized kerogen samples (TOC between 6 and $22 \mathrm{wt} \%$ ) showed an increase in hydrogen index by a factor of one and one half to two over the corresponding whole rock samples. Demineralized samples 1, 2, and 3 lie close to Type II kerogen path (precisely Type IIA-IIB) and sample 4 is within Type II-III (precisely Type IIB) kerogen evolution path. Com-

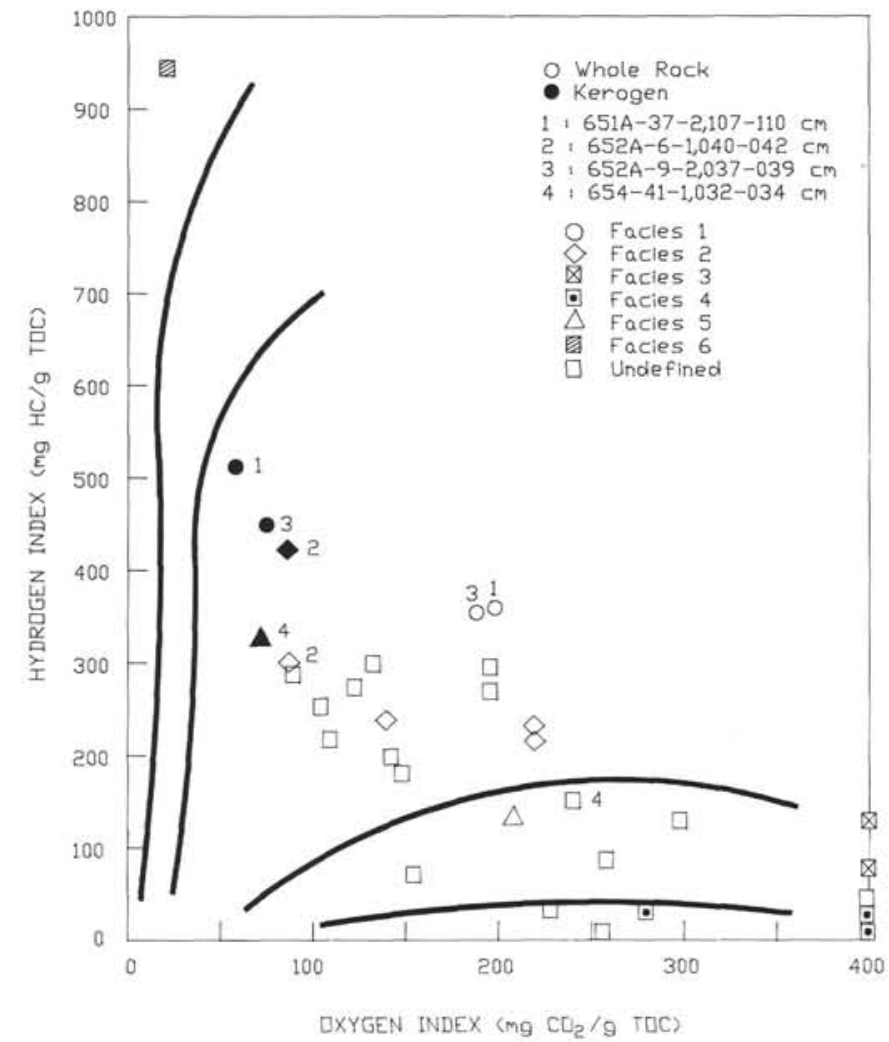

Figure 2. Results of Rock-Eval pyrolysis displayed as hydrogen index vs. oxygen index showing kerogen maturation path (modified after Espitalie et al., 1977). Symbols used for different organic facies and to differentiate between whole rock and kerogen samples.

paratively lower hydrogen index in the whole-rock samples than the partially demineralized kerogens suggests that in these rocks, a major portion of the heavier hydrocarbons were adsorbed by the clay matrix converting to nonvolatile char (Peters, 1986). This effect (lowering of hydrogen index) is generally observed in sediments with low TOC content $(<1.0 \mathrm{wt} \%)$ (Mukhopadhyay et al., 1985b; Peters, 1986). However, present data suggest that organic-carbon-rich ( $>2 \%$ TOC) sediments may also be affected by matrix. The decrease in oxygen index values in the demineralized samples compared to the whole rocks indicates hydrolysis of oxygen-functional groups during strong acid treatment. Some of the organic-lean sediments in Hole 652A and Site 654 in the deeper section have anomalously high production indices $(>0.50)$. Considering the maturity of these sediments, these free bitumens are considered to be allochthonous and were migrated from surrounding organic-rich zones. However, contamination by drilling mud can not be ruled out (Peters, 1986).

\section{Kerogen Microscopy}

\section{Maceral Analysis}

The analytical results from twelve samples (eight of which are from Hole 652A) are shown in Table 2. Most of the organiccarbon-rich Pliocene and Pleistocene sapropels contain abundant biodegraded amorphous liptinite (sapropelinite IIA and IIB) (Kerogen Type IIA-IIB and Type IIB), whereas organiclean sediments contain abundant terrestrial exinite (spores, cuticles, and resinite), vitrinite (including amorphous humic matter or humosapropelinite), and inertinite (Kerogen Type IIB-III, III, and IV of Mukhopadhyay, 1989). Sapropels from Hole 651A contain more particulate liptinite A (acritarch, dinoflagel- 
Table 2. Huminite/vitrinite reflectance and maceral composition in volume percent (mineral matter free basis).

\begin{tabular}{|c|c|c|c|c|c|c|c|c|c|c|c|c|c|c|c|}
\hline \multirow{2}{*}{$\begin{array}{l}\text { Hole-core-section } \\
\text { interval }(\mathrm{cm})\end{array}$} & \multirow{2}{*}{$\begin{array}{l}\text { Sub-bottom } \\
\text { depth }(\mathrm{m})\end{array}$} & \multirow[b]{2}{*}{$R_{0}$} & \multirow[b]{2}{*}{ Std dev } & \multirow[b]{2}{*}{$\mathrm{N}$} & \multicolumn{11}{|c|}{$\begin{array}{l}\text { Maceral composition (volume \%) } \\
\text { (mineral-matter-free basis) }\end{array}$} \\
\hline & & & & & 1 & 2 & 3 & 4 & 5 & 6 & 7 & 8 & 9 & 10 & 11 \\
\hline 651A-28-CC, 1-2 & 271.71 & 0.17 & 0.03 & 26 & 2 & 3 & 11 & 7 & 10 & 10 & 5 & - & 10 & 41 & 1 \\
\hline $651 \mathrm{~A}-37-2,107-110$ & 370.37 & 0.24 & 0.03 & 21 & 2 & 1 & 3 & 5 & 12 & 10 & 2 & - & 39 & 24 & 3 \\
\hline $652 \mathrm{~A}-5-1,40-42$ & 55.80 & 0.25 & 0.04 & 15 & 2 & 2 & 5 & 8 & 8 & 7 & 5 & - & 20 & 43 & - \\
\hline $652 \mathrm{~A}-6-1,45-47$ & 55.85 & 0.26 & 0.05 & 29 & 3 & 2 & 8 & 10 & 8 & 8 & 3 & - & 13 & 44 & 1 \\
\hline $652 \mathrm{~A}-7-4,30-32$ & 69.70 & 0.29 & 0.04 & 31 & 33 & 2 & 9 & 29 & 5 & 3 & 6 & - & 2 & 9 & 2 \\
\hline $652 A-9-2,37-39$ & 86.07 & 0.28 & 0.05 & 29 & 2 & 2 & 6 & 8 & 7 & 8 & 9 & - & 37 & 21 & - \\
\hline $652 \mathrm{~A}-20-6,81-82$ & 198.11 & 0.35 & 0.06 & 12 & 35 & 7 & 11 & 30 & 2 & 2 & 1 & - & 2 & 10 & - \\
\hline $652 A-49-1,116-118$ & 472.02 & 0.64 & 0.06 & 6 & 31 & 32 & 3 & 31 & 1 & - & - & - & - & 2 & - \\
\hline $652 \mathrm{~A}-64-1,100-102$ & 615.20 & 0.65 & 0.02 & 2 & 1 & - & 1 & - & 12 & - & 60 & 24 & 1 & 1 & 1 \\
\hline $652 \mathrm{~A}-73-3,83-85$ & 705.73 & 0.72 & 0.06 & 9 & 19 & 28 & 5 & 32 & 5 & - & - & - & - & 8 & 3 \\
\hline $654-6-4,146-148$ & 46.26 & 0.29 & 0.05 & 7 & 7 & 2 & 11 & 13 & 9 & 5 & 2 & - & 12 & 41 & 1 \\
\hline $654-41-1,32-34$ & 358.12 & 0.45 & 0.05 & 10 & 18 & 5 & 12 & 22 & 5 & 3 & 1 & - & 3 & 26 & 5 \\
\hline
\end{tabular}

Note: $1=$ first cycle + recycled huminite/vitrinite; $2=$ inertinite; $3=$ sporinite + cutinite + suberinite + resinite; $4=$ amorphous humic matter (humosapropelinite); $5=$ liptodetrinite; $6=$ particulate liptinite A (phyto- and zooclasts); $7=$ alginite; 8 $=$ amorphous liptinite derived from alginite (sapropelinite I); 9 = amorphous liptinite derived from phytoplankton and zooplankton (sapropelinite IIA) - not oxidized; 10 = amorphous liptinite derived from phytoplankton or exinite (sapropelinite IIB) - partly oxidized; $11=$ solid bitumen or liquid bitumen

late, etc.) and less humosapropelinite than the sapropels from Hole $652 \mathrm{~A}$ (Table 2). Hole $652 \mathrm{~A}$ shows a progressive change in organic matter types (indicating change in organic facies) from Pleistocene to Messinian to older sediments (Table 2). Pleistocene sapropels contain mixture of sapropelinite IIA (Figs. 3A, -B), IIB (Fig. 3E), alginite (Tasmanites and other unicellular algae), particulate liptinite $\mathrm{A}$ and $\mathrm{B}$, and very minor vitrinite or inertinite. These samples contain abundant unoxidized framboidal pyrite. The proportion of particulate liptinite A (dinoflagellate, etc.) and B (sporinite, cutinite, suberinite) vary considerably among different samples. Organic-lean claystones contain abundant huminite/vitrinite (allochthonous and recycled) and humosapropelinite (Figs. 3C, -D), minor sapropelinite, or alginite. Completely oxidized framboidal pyrite and particulate liptinite A (dinoflagellate, etc.) are also common. Upper Pliocene sapropel $(652 \mathrm{~A}-9-2,037-039 \mathrm{~cm})$ contains dominant sapropelinite IIA and IIB, minor alginite (small unicellular algae of unknown affinity), particulate liptinite A (dinoflagellate and acritarchs), and particulate liptinite B (sporinite and cutinite). However, dinoflagellate and sapropelinite IIA show a slight oxidation effect (partial loss of fluorescence intensity and development of some micrinite) which is a common feature of the material associated with open ocean anoxia. Lower Pliocene and Messinian organic-lean sediments contain mainly oxidized organic matter. They contain abundant recycled vitrinite, inertinite (mainly inertodetrinite and micrinite), humosapropelinite (Fig. 3F), oxidized dinoflagellates. Messinian laminated organicrich claystone shows totally different maceral types than the other Pleistocene sapropels. It contains abundant alginite (Pediastrum?), algodetrinite (lamalginite, Sherwood and Cook, 1984), and sapropelinite I (Mukhopadhyay et al., 1985a) having strong yellow fluorescence in spite of higher maturity. It also contains minor recycled or bitumen-impregnated vitrinites. Sample 652A$73-3,083-085 \mathrm{~cm}$, contains abundant inertodetrinite and other inertinite, recycled vitrinite, and humosapropelinite. The black claystone of $654-6-4,146-148 \mathrm{~cm}$, is very similar in microscopic features to that of Sample $652 \mathrm{~A}-6-1,045-047 \mathrm{~cm}$. It contains abundant sapropelinite IIB and equal amounts of terrestrial exinite, humosapropelinite, sapropelinite IIA. (Figs. 3I, -J). Vitrinites are mostly recycled and sclerotinite and inertodetrinites (Fig. 3J) are the primary inertinite. Moderately organic-rich sediment of the upper Tortonian claystone (654-41-1, 032-034 $\mathrm{cm}$ ) have a different maceral composition than any other sediment. They contain abundant recycled vitrinite, sapropelinite
IIB, humosapropelinite, and moderately high terrestrial exinites (sporinite and cutinite).

\section{Maturation}

Figure 4 and Table 2 show the different vitrinite populations as represented in histograms from six samples of Hole $652 \mathrm{~A}$. These data indicate a decrease of autochthonous vitrinite population toward the deeper part of the section $(652 \mathrm{~A}-49-1,116$ $118 \mathrm{~cm}$ : $472 \mathrm{mbsf}$; 652A-73-3, 083-085 cm: $705 \mathrm{mbsf}$ ). Figure 5 and Table 2 show the range of mean huminite/vitrinite reflectance from top to bottom of the Hole $652 \mathrm{~A}$. It recorded a maturity of $0.30 \% \mathrm{R}_{\mathrm{o}}$ at $100 \mathrm{mbsf}$ and $0.70 \%$ at $700 \mathrm{mbsf}$ which suggest a reflectance gradient of about $0.07 \% R_{o} / 100 \mathrm{~m}$. This is compatible with the high thermal gradient of this basin (about $14^{\circ} \mathrm{C} / 100 \mathrm{~m}$ ). The elevated thermal gradient is caused by proximity to the mantle and to thin continental crust. Pleistocene sediments of greater depth $(370 \mathrm{~m})$ from Hole $651 \mathrm{~A}$ shows immaturity and lower reflectance than sediments in Hole $652 \mathrm{~A}$ and Site 654, however, reflectance gradient is similar. All the Pliocene and Pleistocene sapropels are immature for significant hydrocarbon generation.

Huminite/vitrinite reflectance data are generally correlated to the Rock-Eval pyrolysis data except in the samples which have low TOC content and high production indices. High production indices are caused by migrated bitumen or contamination from the drilling fluids, which also lower the $T_{\max }$ values (especially in Sample 652A-73-3, 083-085 cm). Maturity data indicate matured source rock development below 500 mbsf at Hole $652 \mathrm{~A}$, which is rare in such shallow young deep sea sediments without the effect of an intrusive body (Peters and Simoneit, 1983; Mukhopadhyay et al., 1985b; Rullkotter et al., 1984).

\section{Bitumen Extract}

Results of bitumen extraction in dichloromethane show variations from $68 \mathrm{ppm}(652 \mathrm{~A}-73-3,083-085 \mathrm{~cm})$ to $11,255 \mathrm{ppm}$ (652A-64-1, 100-102 cm) (Table 3). These data indicate a close relationship between extract yield (ppm) and total organic carbon content. Low organic carbon content with elevated bitumen extract in Samples 652A-31-1, 004-006 cm, 652A-49-1, 116-118 $\mathrm{cm}$, and $654-41-1,032-034 \mathrm{~cm}$, indicates presence of migratory hydrocarbons from the deeper and/or surrounding sources. Except in Sample 651A-37-2, 107-110 cm, increase in extract yield is also related to the kerogen type; Type I kerogen in 652-64-1, 


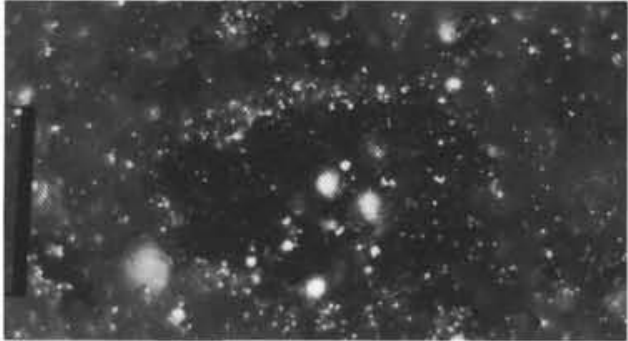

A

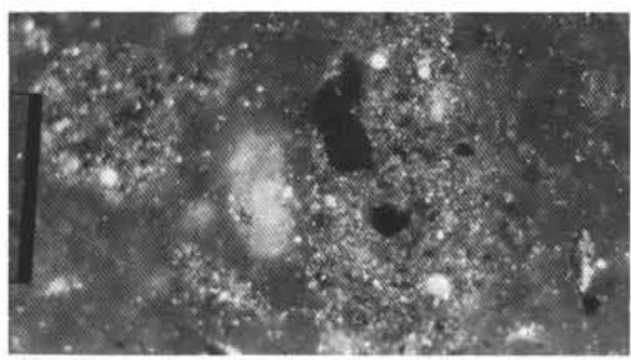

C

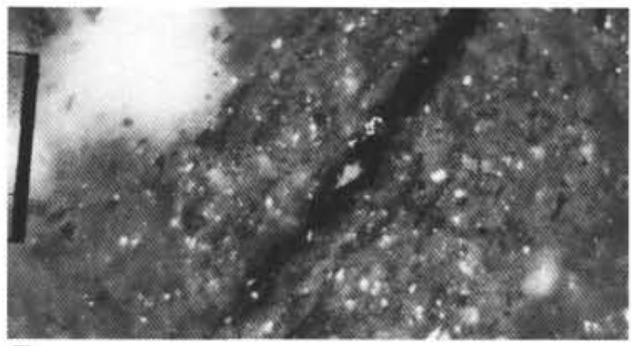

E

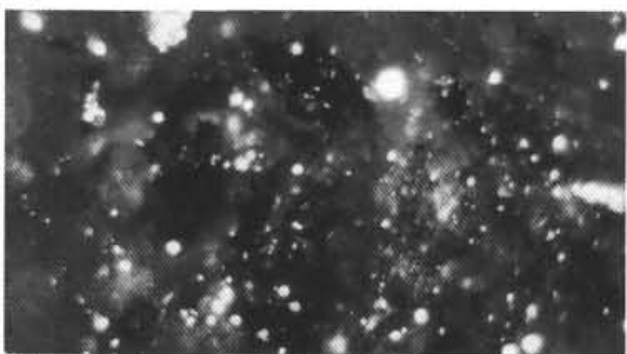

G

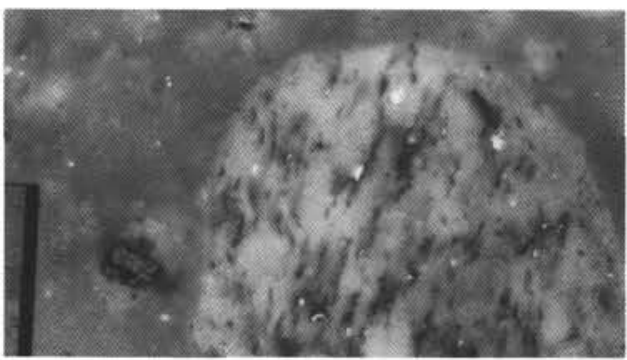

I

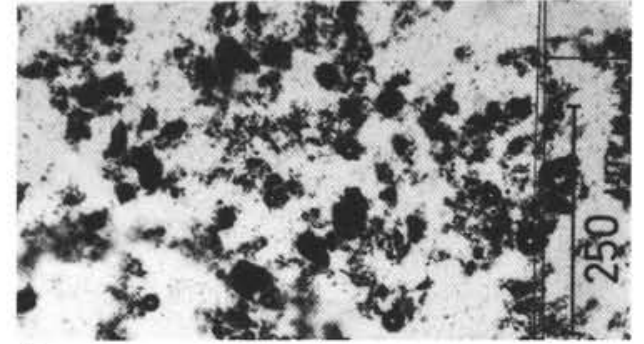

B

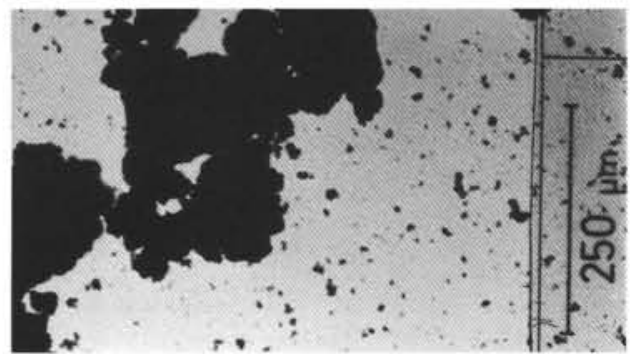

D

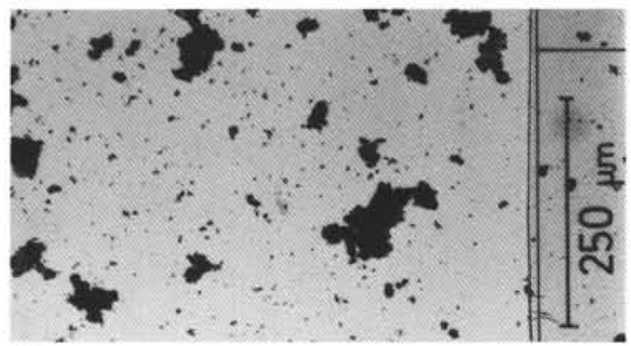

F

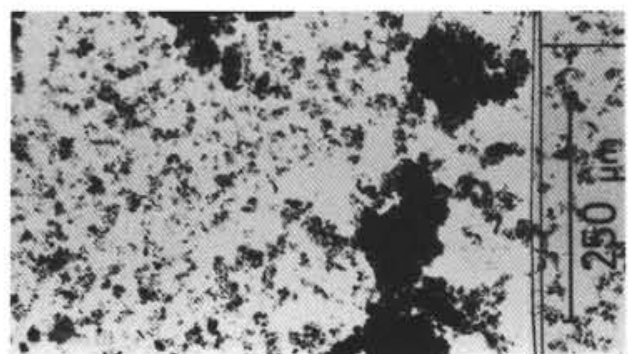

H

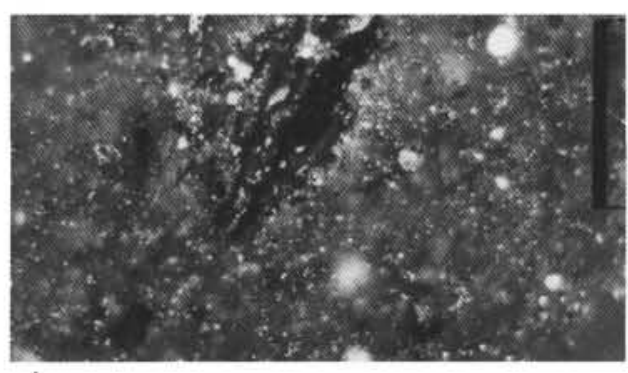

J

Figure 3. Photomicrographs in incident $(\mathbf{A}, \mathbf{C}, \mathbf{E}, \mathbf{G}, \mathbf{I}$, and $\mathbf{J})$ and transmitted $(\mathbf{B}, \mathbf{D}, \mathbf{F}, \mathbf{H})$ white light. Black scale bar for the incident white light indicates $50 \mu \mathrm{m}$; scale for transmitted light indicates $250 \mu \mathrm{m}$. All samples are isolated kerogens. A. Sample 652A-9-2, 037-039 cm: Sapropelinite IIA (dark gray central part), minor huminite (gray spots), and framboidal pyrite (white dots). B. Same sample as A, in transmitted light. Sapropelinite IIA (brown fine-grained fluffy mass), sapropelinite IIB (dark clustered amorphous mass), and huminite (angular dark gray grains). C. Sample 652A-7-4, 032-034 cm; Humosapropelinite (large dark amorphous grain), and fine-grained huminite, and pyrite. D. Same sample as C, in transmitted light. Humosapropelinite (large dark amorphous fluffy grain). E. Sample 652A-20-6, 081-082 cm. Sapropelinite IIB (large dark gray band in the middle), recycled vitrinite, sporinite, inertodetrinite, and pyrite. F. Same sample as E, in transmitted light. Humosapropelinite (dark amorphous fluffy mass). G. Sample 652A-64-1, 100-102 cm. Alginite (Pediastrum?), sapropelinite I (dark gray amorphous mass with faint relict structure of algae), and framboidal pyrite. H. Same sample as G in transmitted light. Sapropelinite I (amorphous fluffy) and alginite. I. Sample 654-6-4, 146-148 cm. Sapropelinite IIB (dark gray amorphous), sporinite, framboidal pyrite. J. Sample 655-2-4, 067-068 cm. Sapropelinite IIA, autochthonous vitrinite, sclerotinite, and framboidal pyrite. 

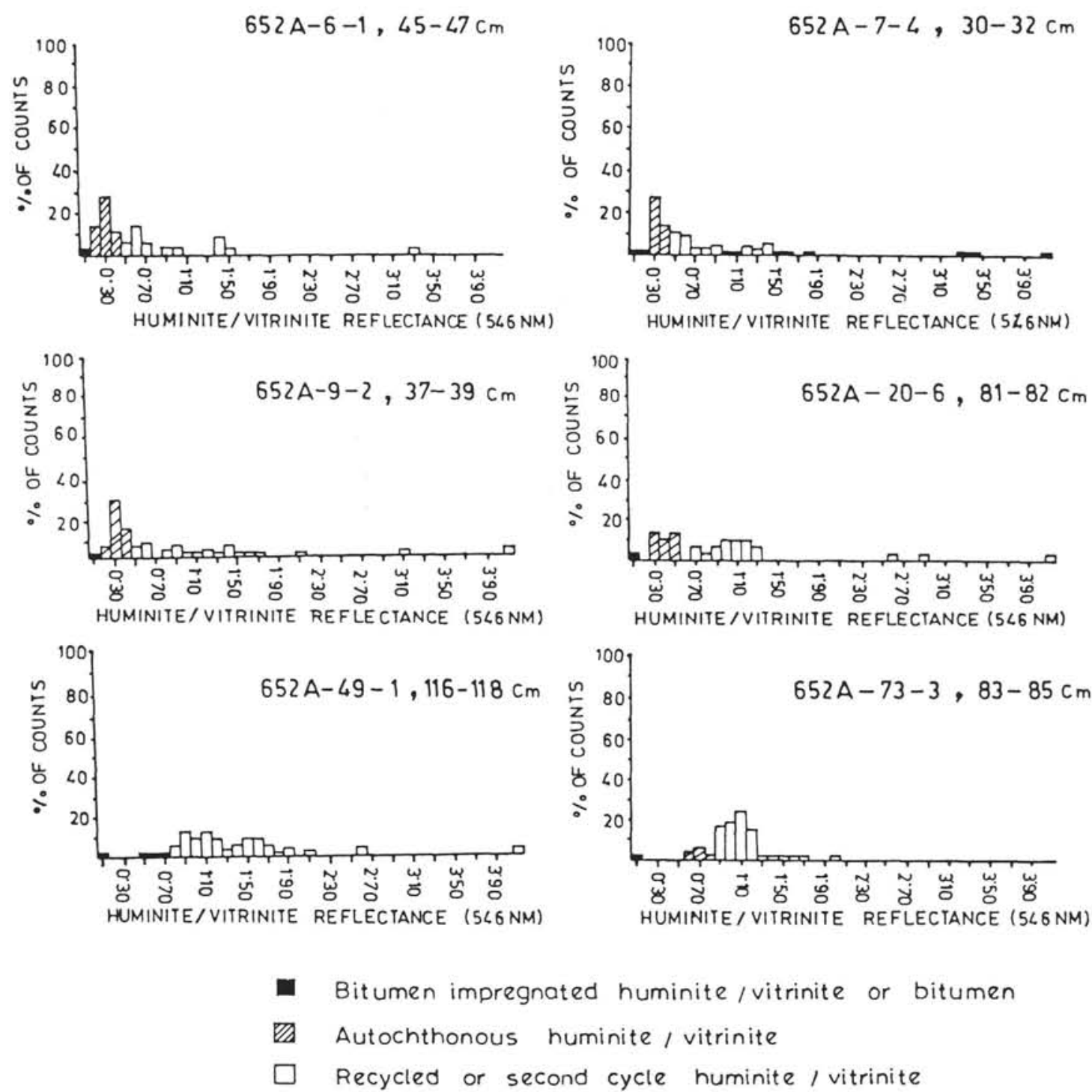

Figure 4. Vitrinite reflectance histogram (relative percent) for samples of different depth from Hole 652A. Symbols indicate three vitrinite populations.

100-102 cm, has the highest extract yield whereas Type IV kerogen in $654-42-4,074-076 \mathrm{~cm}$, has the lowest extract yield. Low extract yield in Sample 651A-37-2, $107-110 \mathrm{~cm}$ (sapropel), is possibly related to low maturity $\left(\mathrm{R}_{\mathrm{o}}=0.24 \%\right)$ which is common also in Cretaceous black shale (Rullkotter et al., 1984).

\section{Pyrolysis-Gas Chromatography}

Pyrolysis-gas chromatography determined the variability and amount of hydrocarbons evolved from an organic sediment during pyrolysis. The hydrocarbons evolved during pyrolysis of the $\mathrm{P}_{2}$ fraction of five samples (Fig. 6), show three trends in the alkane-alkene and other hydrocarbon distribution patterns. Sample $652-64-1,100-102 \mathrm{~cm}$ (whole rock sample; TOC $=8.86 \%$ ) shows a broad distribution of hydrocarbons between $\mathrm{C}_{8}$ and $\mathrm{C}_{21}$; however, alkane-alkene pairs are more dominant hydrocarbons than iso-/cyclo-alkanes and aromatics. Hydrocarbons between $\mathrm{C}_{22}$ and $\mathrm{C}_{29}$ are present in minor amounts compared to $\mathrm{C}_{8}$ to $C_{21}$ compounds. The distribution pattern also indicates that alkane and alkene pairs are evolved in equal amounts between $\mathrm{C}_{8}$ and $\mathrm{C}_{26}$ followed by decreasing alkene contents. Because of similar hydrogen index and maceral compositions, the hydro- carbon distribution patterns of Samples 651A-37-2, 107-110 cm (kerogen; TOC $=19.77 \%$ ) and 652A-9-2, 37-39 cm (kerogen; TOC $=23.73 \%$ ) are compared. These two samples have slightly bimodal n-alkane distribution pattern between $\mathrm{C}_{8}$ and $\mathrm{C}_{30}$. Both samples have a strong predominance of hydrocarbons between $\mathrm{C}_{8}$ and $\mathrm{C}_{17}$; however compounds between $\mathrm{C}_{18}$ and $\mathrm{C}_{27}$ are also abundant to a lesser extent than $\mathrm{C}_{8}$ and $\mathrm{C}_{17}$. Sample 651A-37-2, $107-109 \mathrm{~cm}$, has less high-molecular-weight compounds $\left(\mathrm{C}_{20}\right.$ to $\mathrm{C}_{30}$ ) than the other sample $(652 \mathrm{~A}-9-2,37-39 \mathrm{~cm})$. Aromatics, cycloalkanes, and other compounds dominate over n-alkanes up to $C_{16}$, beyond $C_{17}$ n-alkanes dominate. Partially demineralized Samples 652A-6-1, 40-42 cm (TOC $=20.49 \%)$, and 654$41-1,32-34 \mathrm{~cm}$ (TOC $=6.15 \%$ ), which have different hydrogen index and maceral composition, however, show a similar hydrocarbon distribution pattern. Both samples contain dominantly low molecular hydrocarbons up to $C_{18}$ (mixtures of n-alkanes, aromatics, and cycloalkanes); minor hydrocarbons up to $\mathrm{C}_{30}$ are also present. Both samples contain high aromatics and cycloalkanes between $\mathrm{C}_{8}$ and $\mathrm{C}_{20}$.

The observed variation of pyrolysis-gc patterns indicates the influence of three types of organic matter association; domi- 
MEAN HUMINITE/VITRINITE REFLECTANCE

\section{(Ro)}

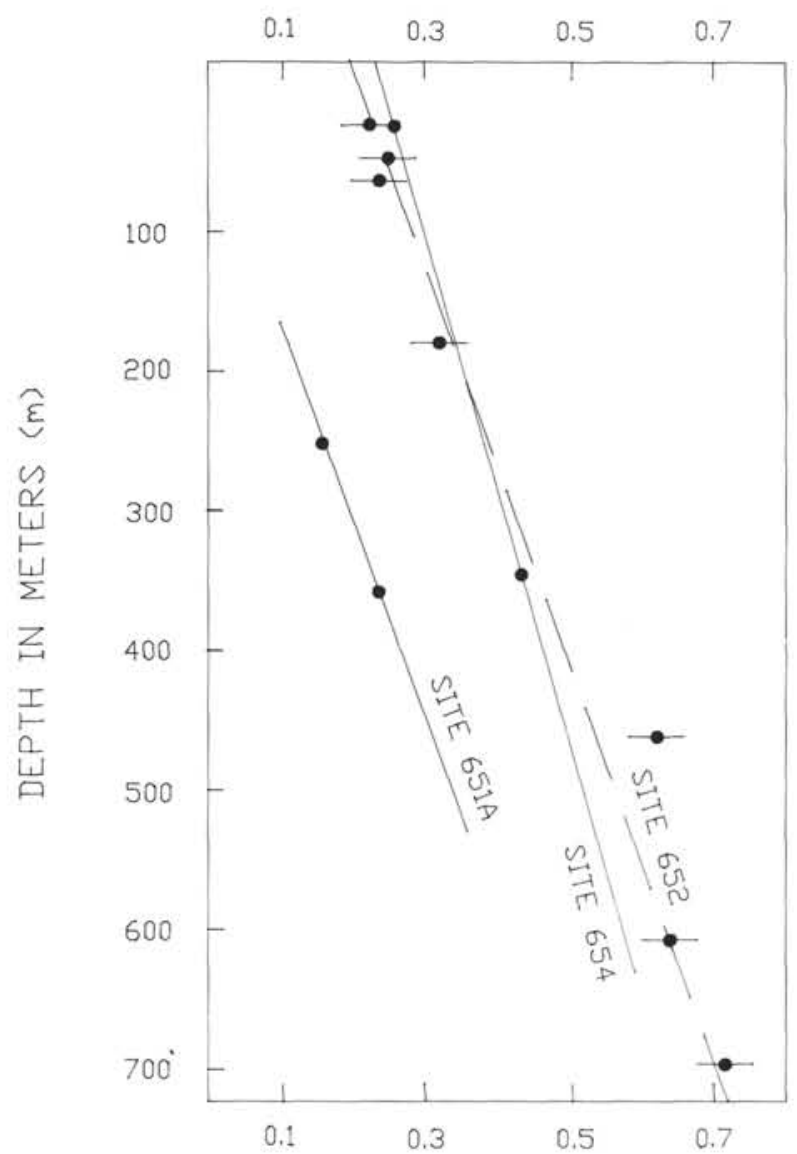

Figure 5. Plot of mean vitrinite reflectance $\left(\mathrm{R}_{\mathrm{o}}\right)$ and depth (mbsf) for Holes $651 \mathrm{~A}$ and $652 \mathrm{~A}$ and Site 654 . For Hole $652 \mathrm{~A}$, mean vitrinite reflectance was plotted along with standard deviation of reflectance measurement.

nantly algal for Sample 652A-64-1, 100-102 cm, dominantly phytoplankton/zooplankton with minor terrestrial exinite for Samples 651A-37-2, 107-110 cm, 652A-9-2, 37-39 cm, mixed terrestrial and marine phytoplankton or oxidized phytoplankton for Samples 652A-6-1, 40-42 cm. Quantitatively, however, Samples $651-37-2,107-110 \mathrm{~cm}, 652 \mathrm{~A}-6-1,40-42 \mathrm{~cm}$, and 652A-9-2, $37-39 \mathrm{~cm}$, generated similar amounts of hydrocarbons in microgram per milligram of partially demineralized kerogen (between 62 and $65 \mu \mathrm{g} / \mathrm{mg}$ for a TOC between 20 and $23 \mathrm{wt} \%$ for those three kerogens) (Table 3). Sample 652A-64-1, 100-102 cm generated two and half times more ( $58.2 \mu \mathrm{g} / \mathrm{mg}$ of rock) than the above three samples because whole rock (TOC $8.86 \mathrm{wt} \%$ ) sample was used for pyrolysis. A partially demineralized sample $(654-41-1,32-34 \mathrm{~cm})$ generated much less hydrocarbons (17.2 $\mu \mathrm{g} / \mathrm{mg}$ of kerogen) than the other samples. However, this sample has much lower TOC after similar demineralization processes. Quantitative comparison of different organic matter types by pyrolysis-gas chromatography is dependent on the organic:inorganic ratio. In samples with lower organic:inorganic (less than 10:90) ratio, more low molecular weight hydrocarbons are generated, because of preferential coking and cracking of high molecular weight hydrocarbons via a free radical mechanism (Taulbee and Seibert, 1987).

\section{SAPROPEL FORMATION AND ORGANIC FACIES}

The origin of Mediterranean sapropel remains controversial and has been attributed to a steep vertical salinity gradient in the water column producing low salinity surface water and high salinity deeper water. This effect triggers a density stratification caused by stagnant bottom water thus preserving pelagic organic matter. This density stratification is caused by ice-sheet meltwater (Williams et al., 1978), increased river water discharge and planktonic productivity (Rossignol-Strick et al., 1982), climatic amelioration (Mangini and Schlosser, 1986), and rainfall. It was suggested that warm humid climate and river water discharge enhanced vertical salinity gradient and controlled stratification forming sapropel in the oxygen-deficient more saline deeper part of the basin.

The present analytical data on organic petrography, supplemented by Rock-Eval pyrolysis and pyrolysis-gas chromatography, do not support the salinity gradient theory, at least for some of the sapropel in Tyrrhenian Sea. Samples 651A-37-2, $107-110 \mathrm{~cm}$, and $652 \mathrm{~A}-9-2,037-039 \mathrm{~cm}$, contain mainly amorphous liptinites (sapropelinite IIA and IIB) mainly derived from dinoflagellate and acritarch. These samples also contain some amount of terrestrial exinites. This may indicate more an open ocean anoxia due to high planktonic productivity caused by the nutrient supply by the rivers and terrestrial input rather than anoxia caused by density stratification where mainly deep water phytoclasts are involved to form sapropel, which would have

Table 3. Bitumem extract and pyrolysis-gas chromatographic data.

\begin{tabular}{|c|c|c|c|c|}
\hline $\begin{array}{l}\text { Hole-core-section } \\
\text { interval }(\mathrm{cm})\end{array}$ & $\begin{array}{l}\text { TOC } \\
\text { (wt \%) }\end{array}$ & $\begin{array}{l}\text { Bitum } \\
\text { ppm }\end{array}$ & $\begin{array}{l}\mathrm{n} \text { extract } \\
\mathrm{mg} / \mathrm{g} \text { TOC }\end{array}$ & $\begin{array}{l}\text { Pyrolysis-gas chromatography } \\
\text { total pyrolysate } \\
\text { (microgram/mg of rock) }\end{array}$ \\
\hline $651 \mathrm{~A}-37-2,107-110$ & $\begin{array}{r}2.18 \\
\left({ }^{*} 19.77\right)\end{array}$ & 127.3 & 5.8 & 62.0 (kerogen) \\
\hline $652 \mathrm{~A}-6-1,40-42$ & $\begin{array}{r}5.49 \\
(* 20.49)\end{array}$ & $2,208.0$ & 40.2 & 63.8 (kerogen) \\
\hline $652 A-9-2,37-39$ & $\begin{array}{r}2.74 \\
(* 23.73)\end{array}$ & & & 65.7 (kerogen) \\
\hline $652 \mathrm{~A}-31-1,4-6$ & 0.18 & 91.2 & 50.7 & - \\
\hline $652 \mathrm{~A}-49-1,116-118$ & 0.14 & 115.9 & 82.1 & - \\
\hline $652 \mathrm{~A}-64-1,100-102$ & 8.86 & $11,255.0$ & 127.0 & 58.2 \\
\hline $652 \mathrm{~A}-73-3,83-85$ & 0.35 & 68.0 & 19.4 & - \\
\hline $654-6-4,146-148$ & 3.17 & 446.9 & 14.1 & - \\
\hline $654-41-1,32-34$ & $\begin{array}{r}1.20 \\
(* 6.15)\end{array}$ & 314.7 & 26.2 & 17.7 (kerogen) \\
\hline $654-42-4,74-76$ & 0.33 & 71.8 & 21.8 & - \\
\hline $655-2-4,67-68$ & 4.11 & 887.5 & 21.6 & - \\
\hline
\end{tabular}

*Data in bracket are for TOC from partially demineralized kerogens. 

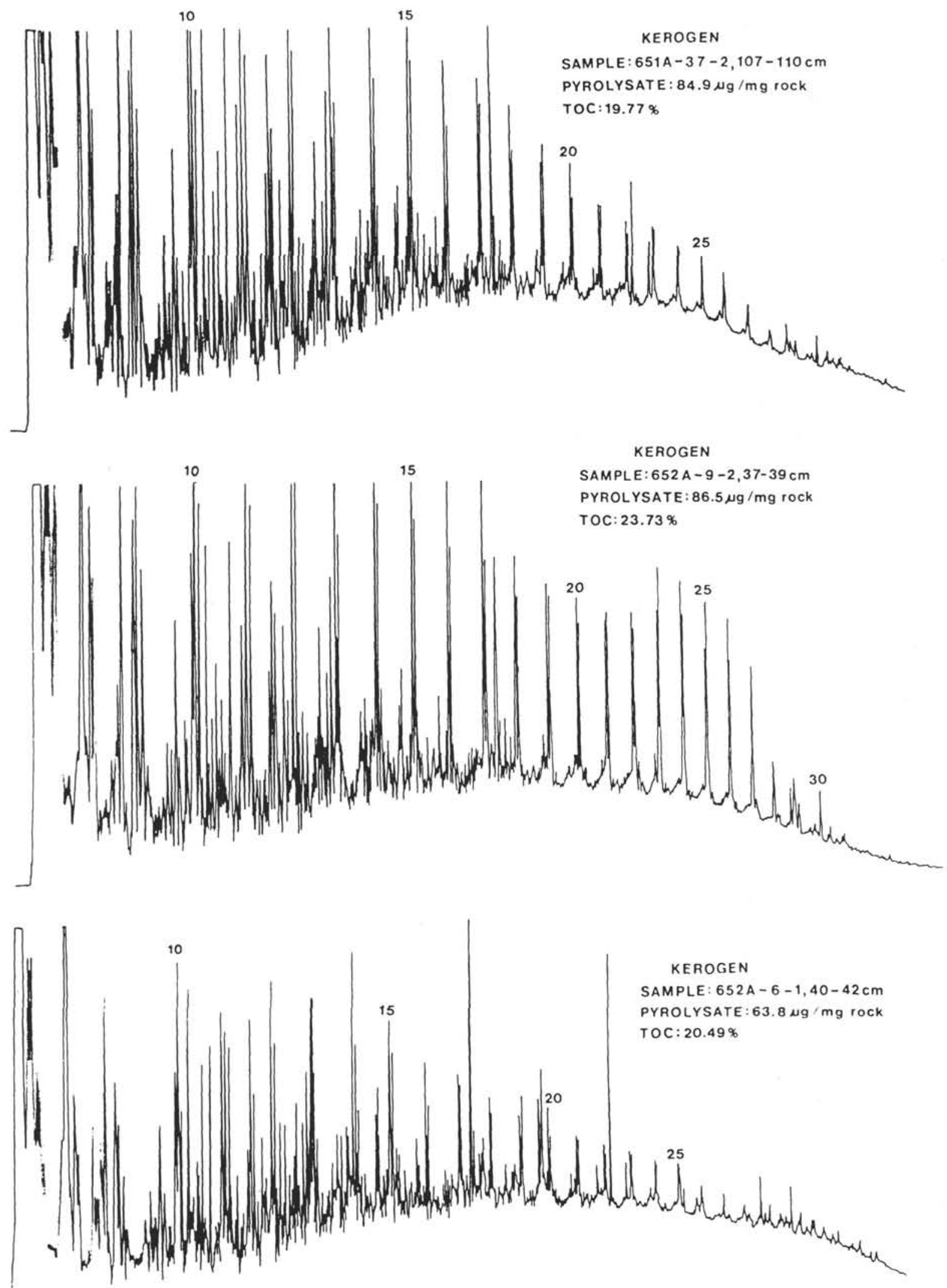

Figure 6. Pyrolysis-gas chromatograms of the $\mathrm{P}_{2}$ fraction in capillary column for five organic-rich samples. For Sample 652A-641, 100-102 cm, whole rock is used, whereas for other four samples partially demineralized kerogens are used. 10, 15, 20 etc. are carbon numbers for $\mathrm{n}$-alkanes. 

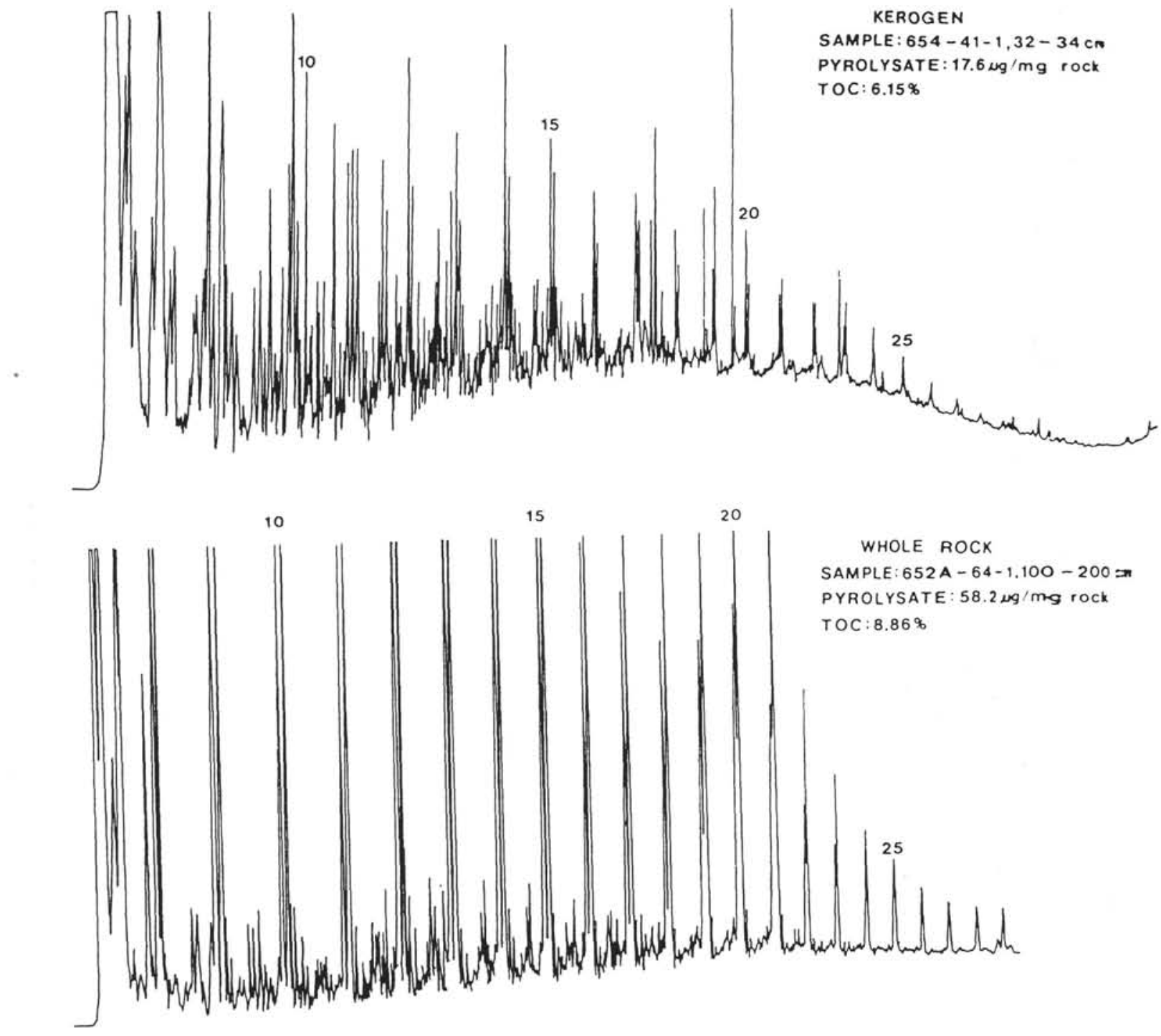

Figure 6 (continued).

been slightly hydrogen deficient than those two Pliocene sapropels (Demaison and Moore, 1980). Some of the Pleistocene sapropel (652A-6-1, 040-042 cm; 654-6-4, 146-148 cm) contains some amount of Tasmanites alginite (shallow marine origin), dinoflagellates of shallow marine origin, and terrestrial exinite. This suggest that oxygen deficiency in the deep ocean is probably caused by material balance of rate of consumption of organic matter and the rate of organic matter transport by turbidites (Habib, 1983; Rullkotter et al., 1984). However, oxygen deficiency due to salinity crisis for the Pleistocene sapropels was probably another alternative explanation.

Based on the data from maceral composition, Rock-Eval pyrolysis, pyrolysis-gas chromatography, and lithostratigraphy of preliminary results of the Shipboard Scientific Party, six organic facies are recognized in these sediments. Figure 2 shows the position of different samples within various organic facies in a hydrogen index vs. oxygen index plot. Salient features of each organic facies are as follows:

Facies 1. Upper Pliocene sapropels (Samples 651A-37-2, $107-110 \mathrm{~cm}$, and 652A-9-2, 037-039 cm). Possible origin: open ocean anoxia due to high planktonic productivity, nutrient sup- ply, and terrestrial input. Major macerals: sapropelinite IIA and IIB. Hydrogen Index: greater than $300 \mathrm{mg} \mathrm{HC} / \mathrm{g}$ TOC.

Facies 2. Pleistocene sapropels and sapropelic layers (Samples 650A-28-CC, 652A-6-1, 040-042 cm, and 045-047 cm, 654$6-4,146-148 \mathrm{~cm})$. Possible origin: Oxygen deficiency due to increased supply of terrestrial and shallow marine organic matter by turbidite or due to salinity crisis due to fresh-water discharge. Major macerals: sapropelinite IIB and presence of Tasmanites algae. Hydrogen Index: between 200 and $300 \mathrm{mg} \mathrm{HC} / \mathrm{g}$ TOC.

Facies 3. Pliocene and Pleistocene light gray nannofossilrich sediments (Samples 652A-7-4, 030-032 cm, and 652A-20-6, 081-083 cm). Possible origin: Open ocean deep water with more input of fresh water organic matter. Major macerals: humosapropelinite and vitrinite. Hydrogen Index: between 75 and 150 $\mathrm{mg} \mathrm{HC} / \mathrm{g}$ TOC.

Facies 4 . Messinian light gray gypsiferous or sandy mudstone (Samples 652A-49-1, 116-118 cm, and 652A-73-3, 083-085 cm, Possible origin: Oxygenated tidal flat or swamp. Major macerals: recycled vitrinite, inertinite, and humosapropelinite. Hydrogen Index: between 10 and $50 \mathrm{mg} \mathrm{HC/g}$ TOC.

Facies 5. Tortonian nannofossil ooze (Sample 654-41-1, 032$034 \mathrm{~cm}$ ) Possible origin: partially oxidizing shallow marine la- 
goon. Major macerals: oxidized sapropelinite IIB, humosapropelinite, and oxidized sporinite/cutinite. Hydrogen Index: 138 $\mathrm{mg} \mathrm{HC} / \mathrm{g}$ TOC.

Facies 6. Messinian light gray mudstone (Sample 652A-64-1, $100-102 \mathrm{~cm})$. Possible origin: Anoxic freshwater lake with algalbacterial mat. Major macerals: alginite, sapropelinite I. Hydrogen Index: $934 \mathrm{mg} \mathrm{HC} / \mathrm{g}$ TOC.

\section{SUMMARY}

The comparison of organic-lean and organic-rich sediments from ODP Holes 650A, 651A, and 652A, and Sites 654 and 655 indicates type, hydrocarbon potential, and maturity of the sediments. The salient features of these sediments are as follows:

1. High organic carbon content in Tyrrhenian Sea samples is associated with Pliocene and Pleistocene post-rift sediments (sapropel and sapropelic layers). Syn-rift sediments are generally organic-lean. However, occasionally organic-rich sediments are also encountered; example Sample 652A-64-1, 100-102 cm, which is an algal-dominated, lacustrine anoxic claystone.

2. Six organic facies are recognized in these sediments which indicate that at least some of the upper Pliocene sapropels were formed possibly due to open ocean anoxia rather than density stratification due to salinity crisis. Sapropels of Pliocene to Pleistocene contain mainly amorphous liptinite (sapropelinite IIA and IIB) formed by the biodegradation of variable proportions of phytoplanktons and terrestrial exinite. Vitrinite, humosapropelinite, and inertinites are the major macerals in the oxic organic facies.

3. Huminite/vitrinite reflectance data indicate mature $(>0.5 \%$ $R_{o}$ ) source rocks below 500 mbsf. Both Holes $651 \mathrm{~A}$ and $652 \mathrm{~A}$ have reflectance gradient of $0.07 \% \mathrm{R}_{\mathrm{o}} / 100 \mathrm{~m}$. Compared to other deep sea sediments, high maturity at relatively shallow depth and younger age indicates high heat flow and presence of thin continental crust in the Tyrrhenian Sea. Analyzed Pliocene and Pleistocene sapropels are immature.

4. Most of the Pliocene and Pleistocene sapropel and sapropelic layers lie within Type II and III (more specifically Type IIA-IIB and Type IIB) source rocks which contain mainly amorphous liptinite and oil/gas prone. The better source rock quality is related to planktonic productivity as open ocean anoxia or as anoxic algal bacterial mat in lake. Messinian syn-rift black claystone is algal-dominated and is a typical oil-prone Type I source rock. Some of the sapropelic layers contain amorphous humic matter and vitrinite and is gas-prone. Dilution of terrestrial input during sapropel formation changes Type IIA kerogen into Type IIB and III source rocks for gas and crude oil. Most of the organic-lean sediments are inertinite/recycled vitrinite-rich and Type IV kerogen and they are nonsource rocks.

Pyrolysis-gas chromatography reveals generation of petroleumlike compounds from all five sapropel and nonsapropelic sediments. Three types of hydrocarbon distributions were generated which are related to organic facies. Quantitatively, Messinian gray claystone (Type I kerogen) generated more than one and half times more hydrocarbons than Pliocene-Pleistocene sapropels (Type IIA-IIB and IIB kerogens).

5. High production indices and bitumen extract yield associated organic-lean sediments indicate hydrocarbon migration from adjacent organic-rich sediments or from deeper sources.

\section{ACKNOWLEDGMENTS}

The author acknowledges the permission of the Texas Bureau of Economic Geology, Austin, Texas, to participate as Shipboard Organic Geochemist for 3 weeks and for providing part of the funds for this work. Appreciation is expressed to Wallace G. Dow, DGSI, Houston, Texas, for part of the geochemical data and review of the earlier version of the manuscript. The author gratefully acknowledges Jean K. Whelan and Martha Tarafa, Woods Hole Oceanographic Institute, Massachusetts, for providing pyrolysis-gas chromatography data. The author ex- presses sincere gratitude to Dieter Birk, Geofuel Research Inc., Sydney, Nova Scotia, for reviewing the final version of the manuscript and other assistance; Jean Sibley word-processed the final version of the manuscript. The author expresses sincere thanks to Jean Mascle, Kim A. Kastens, Der-Duen Sheu, H. L. Ten Haven, and Norman Stewart, ODP, for critically reviewing this manuscript.

\section{REFERENCES}

Demaison, G. J., and Moore, G. T., 1980. Anoxic environments and oil source bed genesis. Am. Assoc. Petrol. Geol. Bull, 64:1179-1209.

Espitalie, J., Laporte, J. L., Madec, M., Marquis, F., Laplat, P., Paulet, J., and Boutefeu, A., 1977. Methode rapide de caracterization des roches-meres, de leur potential petrolier et de leur degre d'evolution. R. Inst. Fr. Pet., 32:23-42.

Habib, D., 1983. Sedimentation-rate-dependant distribution of organic matter in the north Atlantic Jurassic-Cretaceous. In Sheridan, R. E., Gradstein, F. M., et al., Init. Repts. DSDP, 76: Washington (U.S. Printing Office), 781- 794.

Kidd, R. B., Cita, M. B., and Ryan, W.B.F., 1978. Stratigraphy of eastern Mediterranean Sapropel sequences recorded during DSDP Leg $42 \mathrm{~A}$ and their paleoenvironmental significance. In Hsü, K. J., Montadert, L., et al., Init Repts. DSDP, 42, Pt. I: Washington (U.S. Govt. Printing Office), 421-443.

Leg 107 Scientific Party, 1986a. Young Tyrrhenian Sea evolved very quickly. Geotimes, 31:11-14.

1986b. A microcosm of ocean basin evolution in the Mediterranean. Nature, 321:383-384.

Mangini, A. and Schlosser, P., 1986. The formation of eastern Mediterranean sapropels: Mar. Geol, 72:115-124.

Mukhopadhyay, P. K., 1989. Characterization of amorphous and other organic matter types by microscopy and pyrolysis-gas chromatography: Org. Geochem., 14:269-284.

Mukhopadhyay, P. K., Hagemann, H. W., and Gormly, J. R., 1985a. Characterization of kerogens as seen under the aspect of maturation and hydrocarbon generation. Erdoel Kohle, 38:7-18.

Mukhopadhyay, P. K., Rullkotter, J., Schaefer, R. G., and Welte, D. H., $1985 \mathrm{~b}$. Facies and diagenesis of organic matter in Nankai Trough sediments, Deep Sea Drilling Project Leg 87A. In Kagami, H., Karig, D. E., Coulbourn, W. T., et al., Init. Repts. DSDP, 87: Washington (U.S. Govt. Printing Office), 877-889.

Peters, K. E., 1986. Guidelines for evaluating petroleum source rock using programmed pyrolysis. Am. Assoc. Petrol. Geol. Bull., 70:318329.

Peters, K. E., and Simoneit, B.R.T., 1982. Rock-Eval pyrolysis of Quaternary sediments from Leg 64, Sites 479 and 480 , Gulf of California. In Curray, J. R., Moore, D. G., et al., Init. Repts. DSDP, 64, Pt. 2: Washington (U.S. Govt. Printing Office), 925-931.

Rossignol-Strick, M., Nesteroff, W., Olive, P., and Vergnaud-Grazzini, C., 1982. After the deluge: Mediterranean stagnation and sapropel formation: Nature, 295:105-110.

Rullkotter, J., Mukhopadhyay, P. K., and Welte, D. H., 1984. Geochemistry and petrography of organic matter in sediments from Hole 530A, Angola Basin and Hole 532, Walvis Ridge, Deep Sea Drilling Project. In Hay, W. W., Sibuet, J. C., et al., Init. Repts. DSDP, 75: Washington (U.S. Govt. Printing Office), 1069-1087.

Sherwood, N. R., and Cook, A. C., 1984. Low rank oil shales, Part IOrganic Petrology-Final Project Report on NERD \& D Project 79/ 9014, Univ. Wollongong, Australia, 293 p.

Stach, E., Mackowsky, M. T., Teichmuller, M., Taylor, H., Chandra, D., and Teichmuller, R., 1982. Coal Petrology: Berlin (Gebruder Borntraeger).

Taulbee, D. N., and Seibert, E. D., 1987. Comparison of the hydrocarbon pyrolysis products from a Devonian Type II kerogen to those from kerogen/mineral blends: Energy, Fuels, 1:514-519.

Whelan, Jean K., and Tarafa, Martha, 1986. Organic matter in Leg 96 sediments: characterization by pyrolysis. In Bouma, A. H., Coleman, J. M., Meyer, A. W., et al., Init. Repts. DSDP, 96: Washington (U.S. Govt. Printing Office), 757- 766.

Williams, D. F., Thunnell, R. C., and Kennett, J. P., 1978. Periodic fresh water flooding and stagnation of the Eastern Mediterranean Sea during the late Quaternary: Science, 201:252-254.

Date of initial receipt: 30 October 1987

Date of acceptance: 13 January 1989

Ms 107B-117 


\section{APPENDIX}

Sapropelinite IIA and IIB: Both macerals are structureless (less than $10 \mu \mathrm{m})$ under transmitted and reflected light. Sapropelinite IIA shows relict structures of dinoflagellate, acritarch, or other phyto/zooplankton, whereas sapropelinite IIB shows relict structures of sporinite, cutinite, suberinite, and/or slightly oxidized dinoflagellate, coccoliths, and other phytoplanktons. These relict structures are difficult to identify by normal microscopy, however, these structures can easily be identified by scanning electron microscopy. Both macerals are grainy, spongy, and fluffy, however, IIB is more clustered or lumpy than IIA. Sapropelinite IIA is derived from the biodegradation of phytoplankton, zooplankton mixed with bacterial lipid, whereas IIB is derived either from a mixture of terrestrial exinite and partially oxidized phytoplankton or completely from terrestrial exinite or partially oxidized phytoplankton. Both macerals are gray (reflected light) or yellow to brown (transmitted light). In blue-light excitation IIA is yellowish brown and IIB is orange brown.

For the nomenclature of other macerals, see Stach et al. (1982) and Mukhopadhyay et al. (1985a). 